Pedagogik Jurnal Pendidikan, Maret 2015, Volume 10 Nomor 1, ( 32 - 39)

\title{
PERAN GURU BIMBINGAN KONSELING MENGATASI KENAKALAN REMAJA DI SEKOLAH
}

\author{
Oleh : Andi Riswandi Buana Putra*
}

\begin{abstract}
Abstrak
Masa remaja seringkali dihubungkan dengan penyimpangan dan ketidakwajaran. Kenakalan remaja merupakan suatu tindakan atau bentuk gejala patologis sosial yang disebabkan oleh satu bentuk pengabaian sosial. Akibatnya para remaja mengembangkan bentuk perilaku yang menyimpang. Kenakalan remaja disebabkan oleh adanya perubahan pada pribadi remaja, hal tersebut menunjukkan adanya usaha remaja untuk meningkatkan kualitas kepribadiannya. Remaja yang melakukan perbuatan nakal memerlukan perhatian bukan cacian ditimpakan pada mereka. Guru BK mempunyai peran yang sangat penting untuk menangani masalah kenakalan remaja yang terjadi di sekolah.
\end{abstract}

Kata Kunci: guru BK, kenakalan remaja.

\section{PENDAHULUAN}

Secara umum, masa remaja merupakan periode yang sulit untuk ditempuh, sehingga remaja sering dikatakan sebagai kelompok umur bermasalah (the trouble teens). Siswa pada masa remaja cenderung memandang kehidupan secara tidak realistis. Ia melihat dirinya, orang lain, serta fenomena lainnya, sebagaimana yang ia inginkan, bukan sebagaimana adanya. Adanya anggapan bahwa dirinya bukan lagi anak-anak, menyebabkan mereka berusaha meninggalkan perilaku dan sikap kekanakkanakannya untuk diganti dengan sikap dan perilaku yang lebih dewasa. Kedewasaan dalam konteks disini adalah kedewasaan menurut ukuran mereka, yang ternyata masih samar-samar. Mereka merasa mendapatkan kebebasan dalam melakukan suatu hal seperti halnya orang dewasa. Namun apa yang dilakukan oleh anak tersebut merupakan beberapa tingkah laku yang melanggar aturan atau norma yang berlaku, segala macam tindakan siswa yang melanggar aturan seperti tawuran, mabukmabukan, berjudi, membolos, balapan liar dan memalak, hal itu semua bisa digolongkan sebagai kenakalan remaja.

Menurut Hamalik (dalam

Kusumawati dkk, 2012: 6) masa remaja merupakan suatu masa, dimana individu berjuang untuk tumbuh menjadi "sesuatu", menggali serta memahami arti dan makna dari segala sesuatu yang ada. secara psikologis, masa remaja adalah usia dimana individu berintegrasi dengan masyarakat dewasa, usia dimana anak tidak lagi merasa di bawah tingkat orang-orang yang lebih tua melainkan berada dalam tingkatan yang sama, sekurang-kurangnya dalam masalah hak.

Kenakalan dikalangan anak remaja, merupakan masalah sosial yang tak dapat dipungkiri, suatu masalah sosial yang sangat memerlukan perhatian karena sangat mengkhawatirkan, dikatakan mengkhawatirkan karena banyak dari kasus kenakalan remaja telah menjurus kearah kejahatan. Para remaja melakukan tindakan di luar batas, menyimpang dari norma dan tata tertib masyarakat. Berbagai kasus kenakalan remaja yang terjadi menimbulkan ketakutan dan kekhawatiran 
di masyarakat, timbulnya masalah yang lebih rumit dan tampaknya semakin sering terjadi. Istilah kenakalan remaja sering disebut Juvenile Delequency. Menurut Soekanto (dalam Wahidin dkk, 2012: 2) "Juvenile artinya muda, atau belum dewasa dan delequency diartikan kelalaian atau kealpaan".

Adanya iklim lingkungan kehidupan yang kurang sehat, seperti: maraknya tayangan pornografi, kekerasan di televisi, minuman-minuman keras, perjudian, obatobat terlarang atau narkoba, ketidakharmonisan dalam kehidupan keluarga dan lainnya yang sangat mempengaruhi pola perilaku atau gaya hidup terutama pada usia remaja yang cenderung menyimpang dari kaidahkaidah moral (akhlak yang mulia), bergaya hidup mewah, serta persoalan fashion yang identik dengan trend pakaian-pakaian mini, ketat, aksesoris-aksesoris yang mahal, make-up berlebihan yang semuanya itu belum tentu ada manfaatnya hal tersebut merupakan gambaran pola hidup sebagian remaja saat ini.

Menurut Maria, (dalam Wahidin dkk, 2012: 4) lingkungan keluarga yang kurang harmonis sering kali dianggap memberikan kontribusi terhadap munculnya kenakalan pada remaja, karena remaja yang dibesarkan oleh keluarga yang tidak harmonis akan mempersepsi rumahnya sebagai tempat yang tidak menyenangkan dan melakukan hal-hal yang melanggar norma di masyarakat sebagai salah satu cara untuk menyatakan protes pada Orangtua.

Jessor (dalam Nindya dan Margaretha, 2012: 3) "menjelaskan bahwa anak Indonesia yang tinggal dengan orangtua yang melakukan tindak kekerasan akan belajar bagaimana cara berinteraksi dan bersosialisasi dari orangtuanya".
Becker (dalam Aroma dan Suminar, 2012: 2) menyatakan bahwa "pada dasarnya setiap manusia memiliki dorongan untuk melanggar aturan pada situasi tertentu". Tetapi pada kebanyakan orang dorongandorongan tersebut biasanya tidak menjadi kenyataan yang berwujud penyimpangan. Hal tersebut karena orang normal biasanya dapat menahan diri dari dorongan-dorongan untuk berperilaku menyimpang. Kemampuan menahan diri inilah yang seharusnya dipelajari individu selama masa remaja.

Dipandang dari sudut pendidikan, penampilan dan perilaku remaja seperti di atas sangat tidak diharapkan, karena tidak sesuai dengan sosok pribadi manusia Indonesia yang dicita-citakan, seperti tercantum dalam tujuan pendidikan nasional (UU No. 20 Tahun 2003), yaitu: beriman dan bertaqwa terhadap Tuhan Yang Maha Esa, berakhlak mulia, memiliki pengetahuan dan keterampilan, memiliki kesehatan jasmani dan rohani, memiliki kepribadian yang mantap dan mandiri, serta memiliki rasa tanggung jawab kemasyarakatan dan kebangsaan.

Tujuan pendidikan tersebut di atas mempunyai implikasi yang mengharuskan bagi semua tingkat satuan pendidikan untuk senantiasa memantapkan proses pendidikannya secara bermutu ke arah pencapaian tujuan pendidikan tersebut dan mencetak generasi yang unggul, sehat jasmani dan rohani. Namun permasalahannya kenakalan remaja juga menimpa dan menjangkit di lembaga pendidikan. Remaja yang pada usia sekolah seharusnya difokuskan pada menuntut ilmu dan hal yang bermanfaat, kenyataannya justru melakukan berbagai tindakan yang tidak terpuji yang seharusnya tidak mereka lakukan. Dalam hal ini harus ada suatu tindakan guna 
menangani masalah yang terkait dengan kenakalan yang dilakukan siswa di sekolah sedini mungkin, karena bila tidak segera ditangani maka akan semakin besar masalah tersebut dan akan semakin lebih sulit untuk mengatasinya. Semua masalahmasalah siswa tersebut tidak akan mampu diselesaikan hanya oleh guru bidang studi yang mengasuhnya, untuk mengatasi masalah tersebut maka sangatlah perlu jenis dan sarana pendidikan yang memberikan layanan khusus yang diberi tugas untuk menggarap bidang permasalahan tersebut, sehingga potensi siswa bisa berkembang secara optimal dan memperoleh prestasi belajar yang baik. Layanan dalam bidang ini tidak lain adalah layanan Bimbingan dan Konseling yang diberikan oleh tenaga khusus, yakni guru pembimbing atau konselor sekolah.

Hal ini sesuai dengan UndangUndang Sistem Pendidikan Nasional Nomor 20 Tahun 2003 Pasal 1 Ayat 6 yaitu "keberadaan konselor dalam sistem pendidikan nasional dinyatakan sebagai salah satu kualifikasi pendidik, sejajar dengan kualifikasi guru, dosen, pamong belajar, tutor, widyaiswara, fasilitator dan instruktur'. Guru BK sebagai pelaksanan layanan bimbingan dan konseling pada umumnya dapat menangani berbagai permasalahan sesuai dengan bidang kajiannya, baik bimbingan pribadi, sosial, akademik dan karir. Berdasarkan uraian pada latar belakang tersebut guru BK mempunyai peran yang sangat penting untuk menangani masalah kenakalan remaja yang terjadi di sekolah.

\section{KAJIAN PUSTAKA}

\section{Karakteristik Remaja}

Terdapat keragaman dalam menetapkan batasan dan ukuran tentang kapan mulainya dan kapan berakhirnya masa remaja itu. Santrock (2011:402) mengemukakan bahwa "perkembangan di masa remaja diwarnai oleh interaksi antara faktor-faktor genetik, biologis, lingkungan dan sosial". Pasa masa ini sebenarnya tidak mempunyai tempat yang jelas karena tidak termasuk golongan anak tetapi tidak juga golongan dewasa atau tua. Usia remaja, menurut Hurlock (2007:206) "berlangsung kira-kira 13 tahun sampai 16/17 tahun, dan akhir masa remaja bermula dari usia 16/17 sampai 18 tahun, yaitu usia matang secara hukum. Dengan demikian akhir masa remaja merupakan periode yang sangat singkat".

Usia remaja merupakan fase perkembangan yang paling unik. Status remaja sering kali dianggap kurang jelas dan kabur, karena mereka sedang dalam masa ', mencari jati diri', Fenomena perubahan-perubahan psikopisik yang menonjol terjadi dalam masa depan remaja, baik dibandingkan masa-masa sebelumnya maupun sesudahnya, mengundang banyak tafsiran. Demikian halnya dalam menjalani kehidupan sehari-hari, ada suatu kewajiban yang harus dilakukan oleh remaja yang sering dikenal dengan tugas-tugas perkembangan masa remaja. Tugas-tugas perkembangan pada masa remaja difokuskan pada upaya meninggalkan sikap kekanak-kanakan menjadi sikap yang dewasa.

\section{Pengertian Kenakalan Remaja}

Menurut Syafaat Dkk (2008:74)

"Juveline deliquency ialah perilaku jahat (dursila), atau kenakalan yang dilakukan oleh anak-anak muda. Kenakalan remaja meliputi semua perilaku yang menyimpang dari norma-norma hukum pidana yang dilakukan oleh remaja”. Santrock (2011:458) mengatakan bahwa "label kenakalan remaja (juveline delinquent) 
ditetapkan pada remaja yang melanggar hukum atau terlibat dalam perilaku yang dianggap ilegal". Perilaku tersebut akan merugikan dirinya sendiri dan orang-orang di sekitarnya.

Menurut Kartono (2011: 9) "anakanak remaja yang melakukan kejahatan itu pada umumnya kurang memiliki kontrol diri, atau justru menyalahgunakan kontrol diri tersebut, dan suka menegakkan standar tingkah laku sendiri, di samping meremehkan keberadaan orang lain". Kenakalan remaja merupakan perilaku sebagian para remaja yang bertentangan dengan hukum, agama, norma, moral, dan aturan-aturan yang ada di masyarakat. Akibat yang dihasilkan dari perbuatan tersebut dapat merugikan diri sendiri dan orang lain.

Kenakalan remaja itu disebabkan kegagalan mereka dalam memperoleh penghargaan dari masyarakat tempat mereka tinggal. Penghargaan yang mereka harapkan ialah tugas dan tanggung jawab seperti orang dewasa. Mereka menuntut suatu peranan sebagaimana dilakukan orang dewasa. Tetapi orang dewasa tidak dapat memberikan tanggung jawab dan peranan itu, karena belum adanya rasa kepercayaan terhadap mereka.

\section{Jenis - Jenis Kenakalan Remaja}

Menurut Wahidin dkk (2012: 2) dari beberapa bentuk kenakalan remaja dapat di golongkan dalam 4 jenis, yaitu : Kenakalan remaja yang menimbulkan korban fisik pada orang lain, seperti perkelahian, pemerkosaan dan pembunuhan, Kenakalan remaja yang menimbulkan korban materi, seperti pengrusakan, pencurian, pencopetan dan penodongan, Kenakalan sosial yang tidak menimbulkan korban fisik pada orang lain, seperti pelacuran, penyalahgunaan obat, kumpul kebo dan lain-lain, Kenakalan yang melawan status, mengingkari kasus pelajar dengan cara membolos, mengingkari status orang tua dengan minggat dari rumah atau melawan orang tua.

$$
\text { Menurut Asmani }
$$

kenakalan remaja yang sering dilakukan di sekolah adalah sebagai berikut : (1) rambut panjang bagi siswa putra, (2) rambut disemir, (3) mentato kulit, (4) merokok, (5) berkelahi, (6) mencuri, (7) merusak sepeda/motor temannya, (8) pergaulan bebas, (9) pacaran, (10) tidak masuk sekolah, (11) sering bolos, (12) tidak disiplin, (13) ramai di dalam kelas, (14) bermain play station, (15) mengotori kelas dan halaman sekolah.

Dari pendapat di atas, dapat disimpulkan bahwa banyak sekali perilakuperilaku remaja baik di sekolah, masyarakat, keluarga yang dikategorikan masuk dalam ranah kenakalan remaja. Kenakalan ini merupakan perbuatan yang sangat merugikan diri sendiri dan orang lain, terlebih pada harapan dari orang tua kepada anaknya yang senantiasa mengharapkan anak-anak menjadi anak yang sukses dalam mencapai masa depan.

\section{Faktor-Faktor yang Memunculkan Kenakalan Remaja}

Kenakalan remaja merupakan suatu bentuk penyimpangan perilaku yang dilakukan oleh remaja yang sangat perlu sekali perhatian untuk diatasi. Sebelum kita mencari jalan keluar bagi pencegahan dan penanggulangannya, sebaiknya diteliti terlebih dahulu sebab-sebab yang menimbulkan kenakalan tersebut. Menurut Santrock, (dalam Kusumawati, 2012: 6) "faktor yang mempengaruhi kenakalan remaja adalah identitas, kontrol diri, usia, jenis kelamin, harapan terhadap pendidikan dan nilai-nilai di sekolah, proses keluarga, 
pengaruh teman sebaya, kelas sosial ekonomi, kualitas lingkungan sekitar tempat tinggal".

Menurut Nindya dan Margaretha (2012: 3) terbentuknya perilaku menyimpang remaja dipengaruhi oleh tiga aspek yang saling berhubungan. Ketiga aspek tersebut adalah kepribadian yang meliputi nilai individual, harapan, dan keyakinan pada remaja. Aspek kedua sistem lingkungan yang diterima oleh remaja, seperti pada lingkungan keluarga atau teman sebaya. Aspek ketiga adalah sistem perilaku yang merupakan cara yang dipilih remaja untuk berperilaku dalam kesehariannya.

Menurut Siegel \& Welsh (dalam Nindya dan Margaretha, 2012: 2) "beberapa faktor seperti keluarga, sekolah, dan teman sepermainan dianggap menjadi faktor penyebab perilaku kenakalan remaja". Selanjutnya menurut Wahidin dkk (2012: 4) " hal mempengaruhi perilaku kenakalan remaja terdiri dari, Pola Pengasuhan dengan Kekerasan, Kurang Perhatian dan Kasih Sayang, Faktor Lingkungan Luar Rumah". Lemahnya kontrol diri sangat berpengaruh pada perilaku. Seseorang akan mudah terjerumus pada perilaku negatif apabila lemah dalam mengontrol diri, sebaliknya seseorang akan terhindar dari perilaku negatif apabila ia mampu mengontrol diri. Oleh karena itu kontrol diri sangat berperan dalam tingkah laku remaja dan keluarga yang bermasalah merupakan penyebab utama dalam pembentukan masalah emosional pada anak yang dapat mengarah pada masalah sosial dalam jangka panjang.

\section{Karakteristik Kenakalan Remaja}

Karakterisik merupakan ciri-ciri perilaku yang dikelompokkan kedalam ranah kenakalan remaja. Menurut Kartono
(2011 : 49) "ada empat karakteristik kenakalan yang membedakan anak normal dengan nondelinkuen, karakteristik tersebut diantaranya : delikuensi terisolir, delikuensi neurotik, delikuensi psikopatik, dan delikuensi defek mental”. Keempat karakteristik tersebut dapat diuraikan sebagai berikut :

\section{Delikuensi Terisolir (Kenakalan} Terisolir). Kelompok ini merupakan jumlah terbesar dari remaja nakal. Pada umumnya mereka tidak menderita kerusakan psikologis.

2. Delikuensi Neurotik (Kenakalan Neurotik). Pada umumnya, remaja nakal tipe ini menderita gangguan kejiwaan yang cukup serius, antara lain berupa kecemasan, merasa selalu tidak aman, merasa bersalah dan berdosa dan lain sebagainya.

3. Delikuensi Psikopatik (Kenakalan Psipakotik). Delinkuensi psikopatik ini sedikit jumlahnya, akan tetapi dilihat dari kepentingan umum dan segi keamanan, mereka merupakan oknum kriminal yang paling berbahaya.

4. Delikuensi Defek Moral (Kenakalan Defek Moral). Defek (defect, defectus) artinya rusak, tidak lengkap, salah, cedera, cacat, kurang. Delinkuensi defek moral mempunyai ciri-ciri: selalu melakukan tindakan anti sosial, walaupun pada dirinya tidak terdapat penyimpangan, namun ada disfungsi pada inteligensinya.

\section{Dampak Kenakalan Remaja}

Kenakalan remaja merupakan suatu bentuk penyimpangan perilaku yang melanggar norma agama, hukum, dan susila yang dilakukan oleh para remaja. Masyarakat merupakan sarana kehidupan anak remaja di samping keluarga dan lingkungan sekolah. Dalam arti khusus, 
masyarakat merupakan kelompok mansusia yang sudah cukup lama mengadakan interaksi sosial dalam kehidupan bersama yang diliputi oleh struktur serta sistem yang mengatur kehidupan. Di samping itu di dalamnya terdapat pola kebudayaan dan salah satu unsur pokok masyarakat, yakni solidaritas sosial, di dalam kehidupan masyarakat, biasanya terjadi interaksi sosial diantara individu dengan individu yang masing-masing memiliki kesadaran dan pengertian tentang hubungan timbal balik tersebut.

Dengan kenyataannya sering terjadi hubungan individu dengan individu atau bahkan hubungan individu dengan kelompok mengalami gangguan yang disebabkan karena terdapat seorang atau sebagian anggota kelompok di dalam memenuhi kebutuhan hidupnya menimbulkan gangguan terhadap hak-hak orang lain. Gangguan-gangguan yang terjadi tidak jarang muncul dari perbuatanperbuatan anak remaja yang tidak terpuji serta mengancam hak-hak orang lain di tengah-tengah masyarakat.

\section{Peran Guru BK Untuk Mereduksi Kecemasan Siswa Menghadapi Ujian}

Ada beberapa tindakan yang dapat dilakukan dalam upaya untuk mengatasi kenakalan remaja terkait dengan fungsi dan tujuan bimbingan dan konseling sebagai berikut:

\section{Tindakan Preventif}

Tindakan preventif ini merupakan suatu tindakan yang akan dapat mencegah timbulnya kenakalan remaja. Bentuk usaha pencegahan timbulnya kenakalan remaja secara umum, adapun dalam usaha pencegahan secara umum ini dibagi menjadi tiga antara lain: (1) Usaha mengenal dan mengetahui secara ciri umum dan khas remaja, (2) Mengetahui kesulitan-kesulitan yang secara umum dialami remaja karena setiap remaja tidak selalu sempurna dan salah satu penyebab kenakalannya adalah kekurangan atau kelemahan yang tidak diterima oleh remaja tersebut sebagai individu. Dalam tindakan ini berusaha untuk mengetahui kesulitan serta kelemahan yang menimbulkan kenakalan yang dilakukan remaja tersebut, dan (3) Usaha pembinaan remaja, usaha pembinaan remaja ini bertujuan untuk memperkuat sikap mental remaja agar mampu menyelesaikan masalah yang dihadapinya. Upaya Preventif yang dapat dilakukan melalui program BK di sekolah, diantaranya adalah: Pemberian Informasi, Bimbingan Kelompok dan Layanan Mediasi.

\section{Tindakan Represif}

Usaha menindak pelanggaran norma-norma sosial dan moral dapat dilakukan dengan mengadakan hukuman terhadap setiap perbuatan pelanggaran. Dalam menindak terhadap remaja ini ada dua tempat. Di rumah dan dalam lingkungan keluarga, remaja harus mentaati peraturan dan tata cara yang berlaku. Di samping peraturan tentu perlu adanya semacam hukuman yang dibuat oleh orang tua terhadap pelanggaran tata tertib dan tata cara keluarga. Di sekolah dan lingkungan sekolah dalam hal ini maka kepala sekolah lah yang berwenang dalam pelaksanaan hukuman terhadap pelanggaran tata tertib sekolah. Dalam beberapa hal guru juga berhak untuk bertindak atau melimpahan ke pihak guru pembimbing. Pada umunya tindakan represif diberikan dalam bentuk peringatan secara lisan maupun tertulis kepada pelajar yang melakukan kenakalan remaja. Upaya Represif yang dapat dilakukan melalui program BK di sekolah, diantaranya adalah: 
Home Visit dan Konseling Individual Dan Kelompok.

\section{Tindakan Kuratif}

Tindakan kuratif yaitu membimbing anak yang sudah terlanjur melakukan kesalahan, adapun pencegahan jenis ini lebih menitik beratkan kepada pencegahan kenakalan yang bersifat sudah terjadi. Agar kenakalan itu tidak menyebar dan menjangkit pada remaja lain. Fungsi bimbingan dan konseling yang bersifat kuratif, fungsi ini berkaitan erat dengan upaya pemberian bantuan kepada konseli yang telah mengalami masalah, baik menyangkut aspek pribadi, sosial, belajar maupun karir. Upaya Kuratif yang dapat dilakukan melalui program BK di sekolah, diantaranya adalah: Konferensi Kasus dan Alih Tangan Kasus.

Sedangkan menurut Wahidin dkk (2014: 4) "cara penanganan kenakalan remaja yang bersifat ringan yaitu dengan cara yang dilakukan guru bimbingan dan konseling di dalam menanggulangi kenakalan remaja adalah cara kuratif dan cara represif". Hal ini dilakukan untuk membina dan diharapkan tidak akan terjadi kenakalan yang lebih parah lagi.

\section{SIMPULAN}

Kenakalan remaja ialah sikap dan perilaku yang menyimpang dari aturan, peraturan sosial, adat, hukum dan agama.
Oleh karena itu setiap tindakan remaja yang dianggap salah atau tidak pada tempatnya dapat dikatakan atau dikualifikasikan sebagai kenakalan remaja. Remaja yang melakukan perbuatan nakal memerlukan perhatian bukan cacian atau cemoohan yang ditimpakan pada mereka. Perhatian yang diberikan dapat membuka secara psikologis motivasi remaja untuk berbuat baik dan dengan adanya penghargaan yang mereka dan menjadi alat kontrol diri dalam mengarahkan perilaku mereka ke arah yang positif dan ini merupakan salah satu bentuk upaya pemberdayaan remaja terutama yang berperilaku nakal.

Ada beberapa tindakan yang dapat dilakukan dalam upaya untuk mengatasi kenakalan remaja terkait dengan fungsi dan tujuan bimbingan dan konseling melalui upaya preventif, represif dan kuratif. Upaya Preventif yang dapat dilakukan melalui program BK di sekolah, diantaranya adalah: Pemberian Informasi, Bimbingan Kelompok dan Layanan Mediasi. Upaya Represif yang dapat dilakukan melalui program BK di sekolah, diantaranya adalah: Home Visit dan Konseling Individual Dan Kelompok. Upaya Kuratif yang dapat dilakukan melalui program BK di sekolah, diantaranya adalah: Konferensi Kasus dan Alih Tangan Kasus.

\section{DAFTAR PUSTAKA}

Aroma , Iga Serpianing., dan Suminar, Dewi Retno. 2012. Hubungan Antara Tingkat Kontrol Diri DenganKecenderungan Perilaku Kenakalan Remaja. Jurnal Psikologi Pendidikan dan Perkembangan. Vol. 01 No. 02.

Asmani. 2011. Kiat Mengatasi Kenakalan Remaja di Sekolah. Yogjakarta : Buku Biru.

Hurlock, E.B. 2007. Psikologi Perkembangan. Alih bahasa oleh Soedjarmo \& Istiwidayanti. Jakarta: Erlangga.

Kartono, Kartini. 2011. Kenakalan Remaja. Jakarta : Raja Grafindo Persada 
Pedagogik Jurnal Pendidikan, Maret 2015, Volume 10 Nomor 1, (32-39)

Kusumawati, Ambar, dkk. 2012. Pengaruh Pergaulan Kawan Sebaya Terhadap Kenakalan Remaja Siswa Kelas Xi Sma Negeri 1 Natar Tp 2011/2012. Jurnal Bimbingan Konseling. Volume 1, Nomor 1. ISSN 2301-9824.

Nindya P. N dan Margaretha R. 2012.Hubungan antara Kekerasan Emosional pada Anak terhadap Kecenderungan Kenakalan Remaja. Jurnal Psikologi Klinis dan Kesehatan Mental. Vol.1.No.02.

Republik Indonesia. Undang-Undang Sistem Pendidikan Nasional Nomor 20 Tahun 2003.

Santrock, J. W. 2011. Life Span Development. Perkembangan Masa Hidup Jilid 1 (edisi kelima). Jakarta: Erlangga.

Syafaat Dkk. 2008. Peranan Pendidikan Agama Islam Dalam Mencegah Kenakalan Remaja. Jakarta : Raja Grafindo Persada

Wahidin, dkk. 2012. Pemahaman Remaja Tentang Kenakalan Dan Partisipasi Masyarakat Dalam Mengatasi Kenakalan Remaja Di Kecamatan Mamajang Makassar. Jurnal Ilmu Sosial. Vol.I No.1. ISSN 2302-6340 